\title{
Research on College Students' teaching mode based on the subject contest
}

\author{
Han zhijun $^{1}$ Yuan liyan $^{1}$ Gao liqiang ${ }^{1}$ \\ ${ }^{(1}$ Shijiazhuang tiedao university )
}

\begin{abstract}
According to our solar studio teaching experience for many years, this paper proposes to establish an open teaching platform based on subject contest.Some excellent students is not only systematicly teached architectural design skills, but also explore the forefront solar technology in the mode. At the same time, by participating in large-scale design contests, students can learn in practice. This is also making up for the traditional teaching mode, stimulating the biggest interest of the students.
\end{abstract}

Keywords: college students teaching mode subject contest

Architecture design has entered into a new era in twenty-first century, so the ivory tower of the university architectural education also needs to adjust to it. More than 10 years of university higher education enrollment has caused most architectural colleges lack of professional teachers and professional equipment . so how to solve the shortage of teachers and train high quality architectural design talent has become the biggest problem of today's architectural college education.

Moreover under an increasing conflict between resources and environment globally, the society need to combine solar technology with architectural design. In 2008, we began to try to set up solar building studio based on " subject contest" teaching model which gave some savvy students increased solar building design learning opportunities, and builded an advanced architectural design education platform. The studio has been established for five years when we have made some achievements, gained a lot of experience. We will talk about it as follows:

\section{Make up for the defect of tradition- al education}

Architecture belongs to the combination of engineering and art, requires design theory combined with practice, and banlances design inspiration and engineering technology in a wide range of aesthetic and artistic foundation. But at present,our existing architecture teaching systems are immutable and frozen unit type teaching mode.It follows the prescribed order semester 8 weeks or 16 weeks of a curriculum design,which is simply boring and no challenge for the thinking students. And it is already greatly restrict certain students personality development. We need to break through the traditional education mode by having an independent learning environment,

\subsection{How to change the passive learn- ing to active learning?}

The studio learning belongs to the extracurricular hobbies. The studio teaching is based on the traditional teaching, but it is divided into universal learning, project learning, jumping learning and so on several different model for different students. The teachers put the past cramming " teaching " into students' autonomy "learning", combine the forefront building 
technology with architectural design theory, and fundamentally stimulate students' interest in learning. The studio is not for the purpose of the test. By grouping design, collective learning and other teaching methods, it stimulate the students' initiative enthusiasm of study.As a result, Stduents are all through the night in order to complete a design work even forgetting eating and sleeping. The solar studio creates a harmonious learning platform, cultivates team collaboration spirit and plays a complementary and resonance effect.

\subsection{How to become a member of stu- dio?}

The studio member's choice is absolutely volunteered. Member's choice is not only mainly for the architecture students above grade 3, but also is outstanding students. Because only such students have a spare energy to study extracurricular building technology, who are probably not the burden of the studying. whether the students have the potential to mine is in accordance with the usual scores, classmates' recommences, and teachers' recognitions. It is no missing opportunity for the eager students where both teachers and students are free of exchanging in an open environment

\subsection{How to build a free "teaching and learning" mode?}

"Two heads are always better then one".The teaching-learning relation in the studio is relative, where everyone may be a teacher. Firstly, as a teacher, the greatest joy is that students study together with high learning enthusiasm, regardless of the simple computer graphics or the complicated special technology; Second as the next students, the junior students is the best example for the senior students; Moreover, the communication between the same grade students is very good method;finally, the studio uses variety of communication opportunities to expand the horizons of the students. Because of our outstanding performance in 2011 "international solar design competition", the international solar energy society visited our school in 2012 for academic exchange,which caused the students to have the opportunity to communicate with foreign academic institutions.The opening studio provides an active exercise platform for the students' self-study ability, creative ability, research ability and expression ability.

\section{Master professional curriculums and explore advanced solar energy technology}

\subsection{Master professional curriculums}

Professional teachers always think their subjects are very important, ignore " architectural design " ontology. So lack ing of curriculum coordination has become the biggest problem in traditional architecture teaching. A cramming "teaching and learning" system and the final exam are a kind of bondage and misleading for excellent students, or even a " test " shadow. So for architecture discipline,we need pay more attention to the practice, reduce tests, and flexibly use of various techniques to cope with a variety of architectural design task.

The studio learning is established on the basis of three years of professional study, combined with architectural design principle, traditional architectural culture, architectural physics, architectural drawings,architectural design competition and so on. At the same time the studio handsguiding model solves " uselessness of reading " professional doubts and supplied classroom learning deficiency. The studio model emerge help students to perfect professional learning in macro. 


\subsection{Explore advanced solar energy technology}

At present the globe obviously pursuit of "four kinds of saving and environment protection" ,so the construction market of the 21 st century will inevitably based on the green building headed by the solar energy. In china most architectural design tasks are from young building designers, so cultivating energy-saving awareness for the "future of young architects" is a big responsibility and obligation to university.Like the most national building schools, our architecture speciality started relatively late and weak, especially ecological architecture courses are rare. Under so many disadvantages, our studio fills the lack of school teaching, improves the students learning enthusiasm, links with current professional market,and get a series of professional honors for the school.

\section{Learn to practice and Dare to chal- lenge}

\subsection{Learn to practice,}

Only grasping professional knowledge flexibly,the students can gain a foothold in the social competition. The studio uses the full range of students training mode to expand the students' professional knowledge. The studio lasted for more than five years. After a series of hard work in training and competition, the students have a high level of design creativity, and the studio is continuous to access to rich architectural design results. Members of the studio achieved fruitful results in the domestic and foreign architectural design competition. More than 30 students won awards and some projects have put into operation, even become landmark buildings. Especially, the students participated in the Ministry of Construction architecture design competition and won third prize in 2008 ,which great- ly improved the students' professional confidence.

\subsection{Dare to challenge}

The beginning of the architecture is a building design, so daring to be compared to the outside world is the essential spirit of architecture speciality. In architectural design sector, a lot of famous architects are unusually good at university stage, for example,Cui Kai academician had won the first national design competition of architecture students first prize; Maya Ying Lin, a chinese-american architect, obtained vietnam-memorial bid scheme in Washington and so on. These were the successful cases that they dared to challenge during their university stage.

In order to narrow the gap, you must stand together with the giant. The only way to complete it is that you must dare to compete with him. The studio takes part in design competition basically given priority to the solar energy, covering social China's design competition. The participants are famous architecture colleges and universities at home and abroad. Only daring to participate this level of professional competition, we just may find our potential difference and improve ourselves.

\section{Characteristic teaching}

With a wide range of students enrollment,architectural design market is not optimistic.If the College students want to gain social acceptance, the only way is to exercise professional design ability by themselves. It is the best way to become a famous architect by taking part in the architectural design competition.

\subsection{Exercise myself}

Under the hard work of teachers and students, after a series of learning practice training and competition, the students have made a high level of design creation 
ability. The studio obtained the substantial achievements in architectural design competition.

Especially in "China low carbon ecological integration solution competition" held in Peking University, it was not only making multimedia courseware, but also required the students to accept ten experts' questions after making public speaking. It was a full range of exercise for the fledgling college students, University classroom teaching is lack of this exercise, which will become their life's capital and wealth.

\subsection{Work Hard}

The studio learning makes the students' innovation ability, strengthens team spirit .At the same time, the interaction between teachers and students lays a solid foundation for students to society. Each mature winning design opened a door to the students' employment and learning .Many enterprises even write directly that if the students have the various architectural design competition experience, they are haired priority.It also provides favourable conditions to enter the universities for further study.Several old building unversities, such as the southeast university school, for example, the competition winner can get the favour of the teacher in the graduate second-round exam directly. It seems that professional awards may also have a chain of the butterfly effect and get a good job and education opportunity.

\section{Conclusion}

Solar energy as green primary energy, will lead the twenty-first Century architectural design trend. We firmly believe that in the future the solar studio will be interested more and more students.

\section{References}

[1] Zhou Xiang,Liu Xuhong,Wang Yu. Based on virtual design studio architecture teaching method of the $[\mathrm{J}]$. Journal of Architectural Education ,n4 ,pp123125,2007 